\title{
Reshaping the brain: direct lineage conversion in the nervous system
}

\author{
Ryoji Amamoto and Paola Arlotta*
}

\begin{abstract}
Address: Department of Stem Cell and Regenerative Biology, Sherman Fairchild Building 7 Divinity Avenue, Harvard University, Cambridge, MA 02138

*Corresponding author: Paola Arlotta (paola_arlotta@harvard.edu)

Fl000Prime Reports 2013, 5:33 (doi:10.12703/P5-33)

This is an open-access article distributed under the terms of the Creative Commons Attribution-Non Commercial License (http://creativecommons.org/licenses/by-nc/3.0/legalcode), which permits unrestricted use, distribution, and reproduction in any medium, provided the original work is properly cited. You may not use this work for commercial purposes.

The electronic version of this article is the complete one and can be found at: http://fl 000.com/prime/reports/b/5/33

Abstract

During embryonic development, cells in an uncommitted pluripotent state undergo progressive epigenetic changes that lock them into a final restrictive differentiated state. However, recent advances have shown that not only is it possible for a fully differentiated cell to revert back to a pluripotent state, a process called nuclear reprogramming, but also that differentiated cells can be directly converted from one class into another without generating progenitor intermediates, a process known as direct lineage conversion. In this review, we discuss recent progress made in direct lineage reprogramming of differentiated cells into neurons and discuss some of the therapeutic implications of the findings.
\end{abstract}

\section{Introduction}

During embryonic development, cells in an uncommitted pluripotent state undergo progressive epigenetic changes that lock them into a final differentiated state. Famously, Conrad Hal Waddington likened this process to a marble traveling down a downward slope and ending up in one of the many valleys surrounded by impassable hills [1]. This epigenetic landscape model has often been used to explain the restrictive nature of the differentiated cell state.

However, somatic cell nuclear transfer experiments, cellular fusion experiments and, more recently, induced pluripotent stem cell (iPSC) technology have shown that it is possible for a fully differentiated cell to revert back to a pluripotent state, a process called nuclear reprogramming [2-7]. Moreover, it has become clear that not only is it possible for the marble to travel up-slope but it can also jump from valley to valley, a mechanism known as direct lineage reprogramming. In this process, overexpression of various factors can alter cellular identity from one differentiated state into another. Focusing on the central nervous system (CNS), we specifically review and discuss recent progress made in directing the lineage reprogramming of differentiated cells into neurons.

As a gateway for both cell replacement therapy and in vitro disease modeling, direct lineage reprogramming of differentiated cells has the potential to provide a large number of patient-derived, class-specific neurons [8]. To this end, directed differentiation of iPSCs also remains promising; however, there are key differences to consider. Reports demonstrate that nuclear reprogramming to an iPSC state involves a transient tumorigenic pluripotent state that is also susceptible to chromosomal aberrations $[9,10]$. These concerns are less likely to apply to direct reprogramming of differentiated cells. Additionally, because direct reprogramming has been achieved between different cell types, it is reasonable to postulate that a terminal, new cell state may be more readily achieved when the starting population shares some common features or the same developmental origin. Direct lineage reprogramming, of course, comes at a price, since compared with the near-full erasure of epigenetic memory 
during the process of generating iPSCs (and their cell derivatives), neurons obtained by direct lineage reprogramming often maintain transcriptional and epigenetic traces (a "memory") of the cell of origin [11]. Finally, while iPSC generation and differentiation occurs in vitro, recent progress in direct lineage reprogramming indicates that this process could be induced in vivo, bypassing the need to transplant the end product [12-14]. For these reasons, there is great interest in pursuing this avenue as an alternative to iPSC directed differentiation.

\section{Direct lineage conversion into neurons}

One of the first studies to show that direct reprogramming is feasible in the CNS employed astrocytes of the cerebral cortex as the starting cell type. Overexpression of Pax 6 was sufficient to reprogram early postnatal $\mathrm{GFAP}^{+}$astrocytes to Tuj $1^{+}$neurons [15]. Further characterization and improvements from the Götz and Berninger groups have subsequently successfully produced electrophysiologically active glutamatergic and GABAergic neurons from astrocytes, in vitro [15-18]. In addition, endogenous astrocytes have been directly reprogrammed to neuroblasts and neurons upon injury combined with Olig2 repression or via overexpression of the BAM factors (AsclI, Brn2 and Mytl1), respectively [14,19]. These astrocyte-to-neuron studies underscore how minimal manipulation of transcription factor signaling may be sufficient to directly reprogram the identity of differentiated cells of the CNS into neurons.

Collecting a large amount of astrocytes is not always feasible, especially from humans. Thus, several groups have focused on reprogramming more lineage-distant, yet easily obtainable, skin fibroblasts into neurons. In 2010, the Wernig group first demonstrated that transduction of three genes - Ascl1, Brn2, and Mytl1 (BAM) - was sufficient to directly reprogram primary postnatal mouse fibroblasts into induced neurons [20] (Fig. 1). These induced neurons were electrophysiologically active, formed synapses in vitro, and expressed markers of postmitotic neurons. Subsequent studies have shown that induced neurons can be made from human fibroblasts, with different combinations of neuronal developmental genes, miRNAs, small molecule inhibitors, and inhibition of a splicing factor [21-25]. Remarkably, the Brüstle group has attained a conversion yield of $200 \%$ (two neurons for every fibroblast plated) [26]. Since then, direct lineage reprogramming of induced neurons has been achieved from other cell types, including pericytes and, notably, from terminally differentiated cells of a different embryonic lineage, like hepatocytes $[27,28]$. Given that neurons are highly specialized, these groundbreaking studies underscore the vast potential of direct lineage reprogramming to generate even complex cell types.
Figure I. Direct lineage reprogramming of somatic cells into neurons

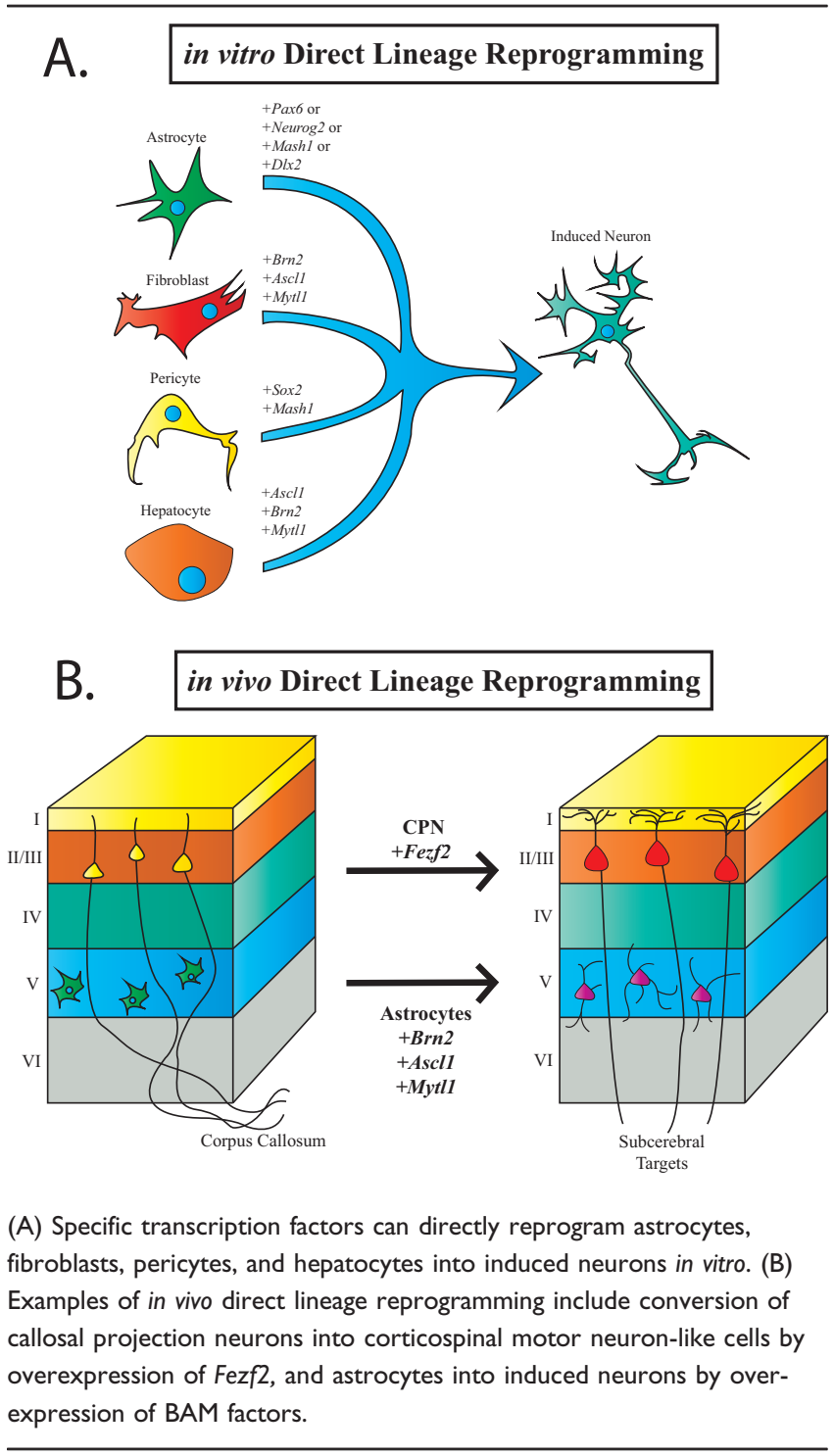

These exciting results have now paved the way for the ultimate challenge of generating specific classes of neurons to recreate the heterogeneity of neurons resident in the mammalian brain and to meet the need for replacement of different classes of neurons in distinct diseases.

In order to produce differentiated neurons that are specifically lost in neurodegenerative disorders like Amyotrophic Lateral Sclerosis, Parkinson's disease, and Alzheimer's disease, several groups have added additional factors to the original BAM cocktail. Mouse and human fibroblasts have been directly reprogrammed into neurons that resemble midbrain dopaminergic neurons, a population that degenerates in Parkinson's disease 
[11,29-31]. The resulting neurons display electrophysiological properties and share some markers of endogenous dopaminergic neurons. Interestingly, the Jaenisch group has shown that upon ectopic transplantation in the striatum, these induced-dopaminergic neurons are able to at least partly integrate into the local circuitry and produce dopamine [29]. Similarly, the Eggan group successfully reprogrammed mouse and human fibroblasts directly into lower motor neurons [32]. Not only were these neurons electrophysiologically active and expressed fewer motor neuron-specific markers but they also integrated into the ventral horn of the developing chick spinal cord upon transplantation. As demonstrated in these studies, the generation of neurons carrying defined, class-specific features might be feasible and especially valuable in the context of disease-related research and therapy.

While these results are encouraging, an important question remains: do the induced neurons need to be functionally and molecularly exact for direct application? This young field is still struggling to define a set of guidelines and standards that could be applicable across experiments to classify cell types generated by direct reprogramming. Global gene expression analysis of induced-dopaminergic neurons and lower motor neurons reveals a cell type that resembles the endogenous population; however, it is also clear that it is not a perfect match $[11,28,32]$. While functionality - i.e. firing properties, neurotransmitter release, appropriate connectivity may be enough for cell replacement therapy, perfectly matched global gene expression profiles may be necessary for reliable disease modeling. These two applications may require separate criteria to define and accept the cell population obtained by direct lineage reprogramming. Similarly, the extent of neuronal-specificity required to properly model a disease in vitro is disease-dependent. For example, Parkinson's disease primarily affects dopaminergic neurons of the substantia nigra pars compacta, while damages to the dopaminergic neurons of the ventral tegmental area are variable [33]. Thus, for the purpose of in vitro disease modeling of Parkinson's disease, it might be more useful to directly reprogram fibroblasts from patients with a familial form of Parkinson's disease into specific dopaminergic neuron classes - those that resemble more closely the neurons of the substantia nigra pars compacta. Different criteria may apply to Alzheimer's disease, a disease in which many neuronal subtypes of the cerebral cortex are affected [34]. In support of this assessment, Qiang et al. isolated fibroblast samples from human patients with Alzheimer's disease and directly reprogrammed them into a heterogeneous population of neurons [35]. While the resulting induced neurons did not appear to be of any specific class, they still recapitulated some of the cellular phenotypes observed in neurons of
Alzheimer's disease patients that were absent in fibroblasts. While the jury is clearly still out and classification criteria for reprogrammed cells are not well defined, it is clear that such guidelines are needed for the field to move forward.

In the context of neurological disorders, one theoretically plausible idea to repair the brain would be to switch a healthy neighboring neuronal subtype into neuronal classes that are lost in disease, using direct reprogramming in vivo, rather than in the dish. Neurons have historically been thought to be immutable, and reversal of their differentiated state impossible. However, nuclear reprogramming studies of olfactory and cortical neurons have shown that even postmitotic neurons from postnatal mice retain nuclear plasticity, as demonstrated in mice by successful generation of pluripotent stem cells via tetraploid complementation with the nucleus of a postmitotic neuron [36-39]. In agreement with this, we have recently demonstrated that it is possible to directly reprogram one neuronal subtype of the cerebral cortex into another by overexpression of a single transcription factor, Fezf2, in vivo [13]. As a master regulator of corticospinal motor neuron generation during development $[40,41]$, Fezf2 induced layer II/III callosal projection neurons to acquire the molecular identity and axonal connectivity of layer $\mathrm{V}$ corticospinal motor neuron. When expressed in cortical neurons of layer IV, Fezf2 was also able to change their electrophysiological properties to resemble those of corticospinal motor neurons [12]. Although lineage conversion was only possible during a defined window of embryonic and postnatal life of the neurons, taken together, these studies highlight not only the possibility of in vivo direct lineage programming of neurons but also the importance of knowledge gained from developmental studies to inform de novo differentiation of specific neuronal subtypes.

\section{Future directions}

Direct lineage reprogramming in the CNS is a concept in its infancy. However, results from the last few years clearly show that this is a field with great potential, both for disease modeling and cell replacement therapy. In the upcoming years, it will be necessary to further our mechanistic understanding of the complex process by which differentiated cells can "change their mind". This knowledge will be necessary to equip researchers with additional molecular tools that facilitate the production of neurons that meet the standards and needs of transplantation, disease modeling, and chemical screening. At the cellular level, it will be important to define the discrete steps of reprogramming and whether intermediate, stable cell states do exist. Initial data show that direct lineage reprogramming to induced neurons is a direct 
process [32,35]. However, it is also conceivable that intermediate cell types are present, but are difficult to identify due to their expression of "unexpected" molecular markers. Support for this hypothesis exists from one of the rare events of natural reprogramming that occurs during Caenorhabditis elegans development. Here, natural direct reprogramming of rectal cells into motor neurons does occur and it includes a discrete intermediate cell type that does not express markers of either rectal cells or motor neurons $[42,43]$. Tools have recently become available for complex molecular profiling of small populations of cells, often down to the single-cell level. These new approaches will facilitate work to shed light on the dynamics of direct lineage reprogramming. Although multiple challenges and questions remain in order to apply direct reprogramming to therapy, these pioneering studies have paved the way for further breakthroughs in what is an exciting and rapidly growing field.

\section{Abbreviations}

CNS, central nervous system; iPSC, induced pluripotent stem cell.

\section{Disclosures}

The authors declare that they have no disclosures.

\section{Acknowledgements}

Work in the Paola Arlotta laboratory is supported by the US National Institute of Health (NS062849), the New York Stem Cell Foundation, the ALS Association and the Harvard Stem Cell Institute to P.A.; P.A. is a New York Stem Cell Foundation-Robertson Investigator.

\section{References}

I. Waddington C: The Strategy of the Genes. London: Allen Unwin; I957: 262.

2. Briggs R, King TJ: Transplantation of Living Nuclei From Blastula Cells into Enucleated Frogs' Eggs. Proc Natl Acad Sci USA 1952, 38:455-63.

3. GURDON JB: Adult frogs derived from the nuclei of single somatic cells. Dev Biol 1962, 4:256-73.

4. GURDON JB, ELSDALE TR, FISCHBERG M: Sexually Mature Individuals of Xenopus laevis from the Transplantation of Single Somatic Nuclei. Nature 1958, 182:64-5.

5. Wilmut I, Schnieke AE, McWhir J, Kind AJ, Campbell KHS: Viable offspring derived from fetal and adult mammalian cells. Nature 1997, 385:810-3.

\section{FlOOOPrime

RECOMMENDED

6. Cowan CA: Nuclear Reprogramming of Somatic Cells After Fusion with Human Embryonic Stem Cells. Science 2005, 309:1369-73.
7. Takahashi K, Yamanaka S: Induction of Pluripotent Stem Cells from Mouse Embryonic and Adult Fibroblast Cultures by Defined Factors. Cell 2006, 126:663-76.

\section{FlOOOPrime}

\section{RECOMMENDED}

8. Ladewig J, Koch $\mathrm{P}$, Brüstle $\mathrm{O}$ : Leveling Waddington: the emergence of direct programming and the loss of cell fate hierarchies. Nat Rev Mol Cell Biol 2013, 14:225-36.

9. Gore A, Li Z, Fung H, Young JE, Agarwal S, Antosiewicz-Bourget J, Canto I, Giorgetti A, Israel MA, Kiskinis E, Lee J, Loh Y, Manos PD, Montserrat N, Panopoulos AD, Ruiz S, Wilbert ML, Yu J, Kirkness EF, Belmonte JCl, Rossi DJ, Thomson JA, Eggan K, Daley GQ, Goldstein LSB, Zhang K: Somatic coding mutations in human induced pluripotent stem cells. Nature 20II, 47 I:63-7.

\section{FlOOOPrime}

\section{RECOMMENDED}

10. Hussein SM, Batada NN, Vuoristo S, Ching RW, Autio R, Närvä E, $\mathrm{Ng}$ S, Sourour M, Hämäläinen R, Olsson C, Lundin K, Mikkola M, Trokovic R, Peitz M, Brüstle O, Bazett-Jones DP, Alitalo K, Lahesmaa R, Nagy A, Otonkoski T: Copy number variation and selection during reprogramming to pluripotency. Nature 201 I, $471: 58-62$

II. Caiazzo M, Dell'Anno MT, Dvoretskova E, Lazarevic D, Taverna S, Leo D, Sotnikova TD, Menegon A, Roncaglia P, Colciago G, Russo G, Carninci P, Pezzoli G, Gainetdinov RR, Gustincich S, Dityatev A, Broccoli V: Direct generation of functional dopaminergic neurons from mouse and human fibroblasts. Nature 201I, 476:224-7.

\section{FlOOOPrime}

12. La Rossa A de, Bellone C, Golding B, Vitali I, Moss J, Toni N, Lüscher C, Jabaudon D: In vivo reprogramming of circuit connectivity in postmitotic neocortical neurons. Nat Neurosci 2013, 16:193-200.

FlOOOPrime RECOMMENDED

13. Rouaux C, Arlotta P: Direct lineage reprogramming of postmitotic callosal neurons into corticofugal neurons in vivo. Nat Cell Biol 2013, I5:2I4-2I.

14. Torper O, Pfisterer U, Wolf DA, Pereira M, Lau S, Jakobsson J, Bjorklund A, Grealish S, Parmar M: Generation of induced neurons via direct conversion in vivo. Proceedings of the National Academy of Sciences 2013, I I 0:7038-43.

\section{FlOOOPrime}

\section{RECOMMENDED}

15. Heins N, Malatesta P, Cecconi F, Nakafuku M, Tucker KL, Hack MA, Chapouton P, Barde Y, Götz M: Glial cells generate neurons: the role of the transcription factor Pax6. Nat Neurosci 2002, 5:308-15

\section{FlOOOPrime

RECOMMENDED

16. Berninger B, Costa MR, Koch U, Schroeder T, Sutor B, Grothe B, Gotz M: Functional Properties of Neurons Derived from In Vitro Reprogrammed Postnatal Astroglia. Journal of Neuroscience 2007, 27:8654-64.

\section{FlOOPrime}

\section{RECOMMENDED}

17. Heinrich C, Blum R, Gascón S, Masserdotti G, Tripathi P, Sánchez R, Tiedt S, Schroeder T, Götz M, Berninger B, McKay RDG: Directing Astroglia from the Cerebral Cortex into Subtype Specific Functional Neurons. PLoS Biol 2010, 8:e 1000373.

\section{FlOOOPrime}

18. Heinrich C, Gascón S, Masserdotti G, Lepier A, Sanchez R, SimonEbert T, Schroeder T, Götz M, Berninger B: Generation of subtype-specific neurons from postnatal astroglia of the mouse cerebral cortex. Nat Protoc 2011, 6:214-28. 
19. Buffo A: Expression pattern of the transcription factor Olig2 in response to brain injuries: Implications for neuronal repair. Proceedings of the National Academy of Sciences 2005, 102:18183-8.

\section{FlOOOPrime}

\section{RECOMMENDED}

20. Vierbuchen T, Ostermeier A, Pang ZP, Kokubu Y, Südhof TC, Wernig M: Direct conversion of fibroblasts to functional neurons by defined factors. Nature 2010, 463:1035-4I.

\section{FlOOOPrime}

\section{RECOMMENDED}

21. Adler AF, Grigsby CL, Kulangara K, Wang H, Yasuda R, Leong KW: Nonviral Direct Conversion of Primary Mouse Embryonic Fibroblasts to Neuronal Cells. Mol Ther Nucleic Acids 2012, I:e32.

22. Ambasudhan R, Talantova M, Coleman R, Yuan X, Zhu S, Lipton SA, Ding S: Direct Reprogramming of Adult Human Fibroblasts to Functional Neurons under Defined Conditions. Cell Stem Cell 20II, 9:113-8.

\section{FlOOOPrime \\ RECOMMENDED}

23. Pang ZP, Yang N, Vierbuchen T, Ostermeier A, Fuentes DR, Yang TQ, Citri A, Sebastiano V, Marro S, Südhof TC, Wernig M: Induction of human neuronal cells by defined transcription factors. Nature 2011.

\section{FlOOOPrime
RECOMMENDED}

24. Xue Y, Ouyang K, Huang J, Zhou Y, Ouyang H, Li H, Wang G, Wu Q, Wei C, Bi Y, Jiang L, Cai Z, Sun H, Zhang K, Zhang Y, Chen J, Fu X: Direct Conversion of Fibroblasts to Neurons by Reprogramming PTB-Regulated MicroRNA Circuits. Cell 2013, 152:82-96.

25. Yoo AS, Sun AX, Li L, Shcheglovitov A, Portmann T, Li Y, Lee-Messer C, Dolmetsch RE, Tsien RW, Crabtree GR: MicroRNA-mediated conversion of human fibroblasts to neurons. Nature 20II, 476:228-3I.

\section{FlOOOPYime
RECOMMENDED}

26. Ladewig J, Mertens J, Kesavan J, Doerr J, Poppe D, Glaue F, Herms S, Wernet P, Kögler G, Müller F, Koch P, Brüstle O: Small molecules enable highly efficient neuronal conversion of human fibroblasts. Nat Meth 2012, 9:575-8.

\section{FlOOOPrime}

\section{RECOMMENDED}

27. Karow M, Sánchez R, Schichor C, Masserdotti G, Ortega F, Heinrich C, Gascón S, Khan MA, Lie DC, Dellavalle A, Cossu G, Goldbrunner R, Götz M, Berninger B: Reprogramming of Pericyte-Derived Cells of the Adult Human Brain into Induced Neuronal Cells. Cell Stem Cell 2012, I I:47I-6.

\section{FlOOOPrime}

28. Marro S, Pang ZP, Yang N, Tsai M, Qu K, Chang HY, Südhof TC, Wernig M: Direct Lineage Conversion of Terminally Differentiated Hepatocytes to Functional Neurons. Cell Stem Cell 2011, 9:374-82.

\section{FlOOOPrime}

\section{RECOMMENDED}

29. Kim J, Su SC, Wang H, Cheng AW, Cassady JP, Lodato MA, Lengner CJ, Chung C, Dawlaty MM, Tsai L, Jaenisch R: Functional Integration of Dopaminergic Neurons Directly Converted from Mouse Fibroblasts. Cell Stem Cell 20II, 9:4I3-9.

\section{FlOOOPrime}

30. Liu X, Li F, Stubblefield EA, Blanchard B, Richards TL, Larson GA, He Y, Huang Q, Tan A, Zhang D, Benke TA, Sladek JR, Zahniser NR, $\mathrm{Li}$ C: Direct reprogramming of human fibroblasts into dopaminergic neuron-like cells. Cell Res 20II, 22:32I-32.
3I. Pfisterer U, Kirkeby A, Torper O, Wood J, Nelander J, Dufour A, Bjorklund A, Lindvall O, Jakobsson J, Parmar M: Direct conversion of human fibroblasts to dopaminergic neurons. Proceedings of the National Academy of Sciences 20I I, I 08: 10343-8.

\section{FlOOOPrime}

32. Son EY, Ichida JK, Wainger BJ, Toma JS, Rafuse VF, Woolf CJ, Eggan K: Conversion of Mouse and Human Fibroblasts into Functional Spinal Motor Neurons. Cell Stem Cell 20II, 9:205-18.

\section{FlOOOPrime}

33. Sulzer D, Surmeier DJ: Neuronal vulnerability, pathogenesis, and Parkinson's disease. Mov Disord 20I3:n/a.

34. Huang Y, Mucke L: Alzheimer Mechanisms and Therapeutic Strategies. Cell 20I2, 148:1204-22.

35. Qiang L, Fujita R, Yamashita T, Angulo S, Rhinn H, Rhee D, Doege C, Chau L, Aubry L, Vanti WB, Moreno H, Abeliovich A: Directed Conversion of Alzheimer's Disease Patient Skin Fibroblasts into Functional Neurons. Cell 20II, I46:359-7I.

\section{FIOOOPrime
RECOMMENDED}

36. Eggan K, Baldwin K, Tackett M, Osborne J, Gogos J, Chess A, Axel R, Jaenisch R: Mice cloned from olfactory sensory neurons. Nature 2004, 428:44-9.

\section{FlOOOPrime}

37. Kim J, Lengner CJ, Kirak O, Hanna J, Cassady JP, Lodato MA, Wu S, Faddah DA, Steine El, Gao Q, Fu D, Dawlaty M, Jaenisch R: Reprogramming of Postnatal Neurons into Induced Pluripotent Stem Cells by Defined Factors. STEM CELLS 20II, 29:992-1000

\section{FlOOOPrime
RECOMMENDED}

38. Li J, Ishii T, Feinstein P, Mombaerts P: Odorant receptor gene choice is reset by nuclear transfer from mouse olfactory sensory neurons. Nature 2004, 428:393-9.

\section{FIOOOPrime}

39. Osada T: Developmental Pluripotency of the Nuclei of Neurons in the Cerebral Cortex of Juvenile Mice. Journal of Neuroscience 2005, 25:8368-74.

\section{FlOOOPrime
RECOMMENDED}

40. Molyneaux BJ, Arlotta P, Hirata T, Hibi M, Macklis JD: Fezl Is Required for the Birth and Specification of Corticospinal Motor Neurons. Neuron 2005, 47:817-31.

\section{FlOOOPrime}

41. Rouaux C, Arlotta P: Fezf2 directs the differentiation of corticofugal neurons from striatal progenitors in vivo. Nat Neurosci 2010, 13:1345-7.

\section{FlOOOPrime}

42. Jarriault S, Schwab Y, Greenwald I: A Caenorhabditis elegans model for epithelial-neuronal transdifferentiation. Proceedings of the National Academy of Sciences 2008, 105:3790-5.

\section{FlOOOPrime}

\section{RECOMMENDED}

43. Richard JP, Zuryn S, Fischer N, Pavet V, Vaucamps N, Jarriault S: Direct in vivo cellular reprogramming involves transition through discrete, non-pluripotent steps. Development 201I, 138: | 483-92.

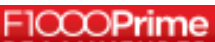

